\title{
Treatment of Localized Vulvar Pain with Neural Therapy: A Case Series and Literature Review
}

\author{
Modesto Rey Novoa ${ }^{a, b}$ Montserrat Muñoz-Sellart ${ }^{b-d} \quad$ Marta Catalán Soriano ${ }^{b, e}$ \\ David Vinyes ${ }^{\text {b-d }}$ \\ ${ }^{a}$ Department of Obstetrics and Gynecology, Hospital Universitario de Burgos, Burgos, Spain; ${ }^{b}$ Campus Docent de

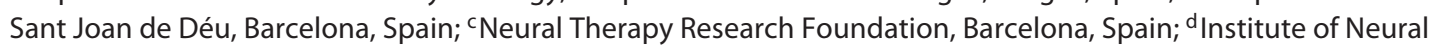 \\ Therapy and Regulatory Medicine, Sabadell, Barcelona, Spain; ${ }^{~}$ Department of Obstetrics and Gynecology, Hospital \\ del Vendrell, Tarragona, Spain
}

\section{Keywords}

Vulvodynia - Vulvar pain · Vulvar vestibulitis · Local anesthetics $\cdot$ Procaine $\cdot$ Neural therapy

\begin{abstract}
Background: Localized vulvar pain (LVP) is a common condition among fertile women, with physical and psychosexual implications. Treatment is complex with limited benefits. Neural therapy is a regulatory therapy that uses injections of local anesthetics in low concentrations in specific points to treat different conditions. Case Presentation: We present the cases of 5 women, ages 33-44 years, with LVP treated with procaine $0.5 \%$ injections in painful points. Complete relief from pain occurred in 2 patients, and significant improvement in 3 . Only 1 or 2 sessions were required. Initial VAS score was $\geq 70$ and decreased to $\leq 30$ after the intervention. The improvement was maintained over time, with a minimum follow-up period of 6 months. None of the patients were able to have sex or use tampons due to pain, but they were able to resume after the intervention. Conclusions: In this case series, local injections of procaine showed a favorable outcome. Future randomized clinical trials could help elucidate the role of this intervention in LVP.
\end{abstract}

(C) 2021 S. Karger AG, Basel
Behandlung von lokalisierten Vulvaschmerzen mit Neuraltherapie: Eine Fallserie und Literaturübersicht

\section{Schlüsselwörter}

Vulvodynie - Vulvaschmerz - Vulväre Vestibulitis . Lokalanästhetika $\cdot$ Procain · Neuraltherapie

\section{Zusammenfassung}

Hintergrund: Lokalisierter Vulvaschmerz (localized vulvar pain, LVP) ist eine häufige Erkrankung bei Frauen im gebärfähigen Alter, die sowohl physische als auch psychosexuelle Auswirkungen hat. Die Behandlung ist komplex und von begrenztem Nutzen. Bei der Neuraltherapie handelt es sich um eine Regulationstherapie, bei der Lokalanästhetika in niedrigen Konzentrationen an bestimmten Punkten injiziert werden, um verschiedene Erkrankungen zu behandeln. Fallbericht: Wir berichten über die Fälle von fünf Frauen im Alter zwischen 33 und 44 Jahren mit LVP, die Injektionen von Procain 0,5\% in die Schmerzpunkte erhielten. Bei 2 Patientinnen wurde eine vollständige Schmerzlinderung erreicht und bei 3 Patientinnen kam es zu einer signifikanten Verbesserung. Es waren nur eine oder zwei Sitzungen notwendig. Der VAS-Score betrug initial $\geq 70$ und ging nach der Intervention auf Werte $\leq 30$ zurück. Die Verbesserung blieb im Zeitverlauf über eine Nachbeobachtungszeit von mindestens 6 Monaten 
bestehen. Aufgrund der Schmerzen konnte keine Patientin Geschlechtsverkehr haben oder Tampons benutzen, wohingegen dies nach der Intervention möglich war. Schlussfolgerungen: In der vorliegenden Fallserie waren lokale Procain-Injektionen mit positiven Outcomes verbunden. Zukünftige randomisierte klinische Studien können helfen, die Bedeutung dieser Intervention bei LVP zu klären.

(c) 2021 S. Karger AG, Basel

\section{Introduction}

\section{Localized Vulvar Pain}

Localized vulvar pain (LVP), previously known as vulvar vestibulitis or localized vestibulodynia, is defined as chronic pain and/or stinging located in the vulvar vestibule or the clitoris, without an identifiable cause that persists for 3 months or more. It can be provoked (most frequently), spontaneous, or mixed [1].

LVP is the most common subtype of chronic vulvar pain [2], with an unknown prevalence and incidence. The prevalence of chronic vulvar pain is estimated between 3 and $15 \%$ [3-5]. Many women affected by vulvar pain do not seek medical advice; only $50 \%$ do, and among them, only a minority (1.4\%) are diagnosed with vulvodynia [6]. LVP has a negative impact on health, self-esteem, mood, relationships, and quality of life for women who suffered from it $[7,8]$.

Although different etiopathogenic mechanisms have been proposed, no definitive cause has been defined. The 2 main etiopathogenic mechanisms are $[6,9]$ : neurogenic origin due to damage of peripheric nervous terminations (vestibular) and inflammatory origin due to chronic inflammation process in the vestibule with peripheric sensitization [10]. Both mechanisms would produce central sensitization (spinal cord) and change nociceptive transmission in the central nervous system, perpetuating pain.

The diagnosis is clinical, excluding specific causes of vulvar pain, such as infection, inflammation, neoplastic or atrophic diseases [6].

Although different treatments have been proposed, there is no specific treatment. A multidisciplinary approach is proposed considering the following interventions: medication, psychosexual therapy, physical therapy, neuromodulation procedures, and surgery techniques [11]. None of the proposed treatments is effective in permanently eliminating symptoms. The search for new therapeutic approaches for LVP is a need and a challenge [9].

\section{Neural Therapy}

Neural therapy (NT) is a regulatory treatment that consists of an injection of local anesthetics (LA), at low concentration ( 0.5 or $1 \%)$, into specific points with a therapeutic and diagnostic purpose, local anesthesia not being the goal (except for diagnostic issues) [12, 13]. The most widely used LA in NT is procaine, due to its safety profile, its prolonged action beyond pharmacological duration, and its additional favorable effects on microcirculation $[12,14]$. The objective is the generation of a directed stimulus (through the needle) and the selective extinction of other stimuli (through the LA), thus affecting the nervous system and tissue perfusion [15] and allowing the interruption of positive feedback loops (vicious circles) of pain and other pathological processes $[12,13,15]$. The treatment modalities in NT are local therapy (injection in trigger points and in areas of tension or pain on palpation) [16]; segmental therapy (injection in reflex areas of HEAD, sympathetic ganglia, nerve roots, or peripheral nerves) $[12,13]$; and interference field therapy (injection into areas of chronic alteration of a structure of the organism that can cause or maintain a symptomatic alteration in another area of the organism) $[10,12,13]$.

We present a case series of 5 women with LVP treated with procaine $0.5 \%$ injections in painful vulvar points (local therapy modality of NT). All patients were attended as outpatients in a gynecology unit of a tertiary hospital between October 2016 and October 2017. The technique consisted of injecting at the painful points between 0.5 and $1 \mathrm{~mL}$ of $0.5 \%$ procaine with hydrochloric acid as excipient (Procaine Serra), with a hypodermic needle of $0.30 \times 12 \mathrm{~mm}(30 \mathrm{G} \times 1 / 2$ Sterican Braun $)$ at the subcutaneous level (depth between 1 and $2 \mathrm{~mm}$ ). Pain related to LVP was measured by the visual analogue scale (VAS) of $0-100$ (VAS $=0$, no pain; VAS $=100$, maximum pain).

The purpose of this case report is to motivate future studies to evaluate the efficacy of local procaine injections to treat LVP.

\section{Cases Presentation}

\section{Case 1}

A 33-year-old single Caucasian woman with provoked LVP for 5 months reported to the gynecology department. She had a body mass index (BMI) of 22.3, was nulliparous, used oral combined hormonal contraception (OCHC), and suffered from polycystic ovary syndrome and recurrent candida vulvovaginitis (2 episodes at age 21 years and 1 at 28 years).

She had suffered from vulvar pain for 5 months that appeared immediately after genital contact or manipulation and had itching characteristics. The duration of pain was from 48 to $72 \mathrm{~h}$ after the onset and intensity measured by VAS was 70 . She was unable to have sex or insert tampons.

On examination, no discoloration changes were observed either in the vagina or in the vulva, and the flow was normal. Vestibular palpations at 5 and $7 \mathrm{~h}$ were painful. It was defined as provoked LVP. No previous treatment had been made.

Procaine $0.5 \%$ injection was performed on painful localizations (5- and 7-time zones). The patient presented pain of VAS $=20$ and 
Table 1. Demographic and clinical characteristics of the patients

\begin{tabular}{|c|c|c|c|c|c|c|c|c|}
\hline & $\begin{array}{l}\text { Age, } \\
\text { years }\end{array}$ & $\begin{array}{l}\text { Civil } \\
\text { status }\end{array}$ & $\begin{array}{l}\text { Medical } \\
\text { history }\end{array}$ & $\begin{array}{l}\text { Surgical } \\
\text { history }\end{array}$ & $\begin{array}{l}\text { Gynecological } \\
\text { diseases }\end{array}$ & $\begin{array}{l}\text { Obstetrical } \\
\text { history }\end{array}$ & $\begin{array}{l}\text { Contra- } \\
\text { ception }\end{array}$ & Medication \\
\hline Case 1 & 33 & Single & None & None & $\begin{array}{l}\text { POS } \\
\text { Recurrent } \\
\text { vulvovaginitis }\end{array}$ & Nulliparous & $\mathrm{OCHC}$ & None \\
\hline Case 2 & 35 & Married & None & $\begin{array}{l}\text { Ovarian cystectomy } \\
\text { Caesarean } \\
\text { Episiotomy } \\
\text { Perineal tear suture }\end{array}$ & $\begin{array}{l}\text { Dysmenorrhea } \\
\text { Endometriosis }\end{array}$ & $\begin{array}{l}\text { G2D2A0 } \\
\text { P1: Caesarean } \\
\text { P2: forceps }\end{array}$ & $\mathrm{OCHC}$ & None \\
\hline Case 3 & 33 & Married & None & Episiotomy & None & $\begin{array}{l}\text { G1D1A0 } \\
\text { P: vaginal }\end{array}$ & Condom & $\begin{array}{l}\text { Promestriene (v) } \\
\text { Chlorhexidine (t) }\end{array}$ \\
\hline Case 4 & 44 & Married & None & Episiotomy & Dysmenorrhea & $\begin{array}{l}\text { G1D1A0 } \\
\text { P: vacuum }\end{array}$ & $\mathrm{OCHC}$ & $\begin{array}{l}\text { Fluomizin (v) } \\
\text { Antifungal (t) } \\
\text { Corticosteroids (t) }\end{array}$ \\
\hline Case 5 & 33 & Married & $\begin{array}{l}\text { Crohn's } \\
\text { disease } \\
\text { Hypo- } \\
\text { thyroidism }\end{array}$ & $\begin{array}{l}\text { Episiotomy } \\
\text { Perineal tear suture }\end{array}$ & $\begin{array}{l}\text { Recurrent } \\
\text { vulvovaginitis }\end{array}$ & $\begin{array}{l}\text { G1D1A0 } \\
\text { P: forceps }\end{array}$ & $\begin{array}{l}\text { OCHC } \\
\text { Vaginal ring }\end{array}$ & $\begin{array}{l}\text { Azatioprine (o) } \\
\text { Mesalazine (r) } \\
\text { Levothyroxine (o) }\end{array}$ \\
\hline
\end{tabular}

G, gestation; D, delivery; A, abortion; POS, polycystic ovary syndrome; OCHC, oral combined hormonal contraception; (v), vaginal; (t), topic; (o), oral; (r), rectal.

scarce self-limiting bleeding related to the punctures. VAS after the intervention improved from 70 to 20 , always associated with vulvar contact or manipulation. The improvement was maintained during the follow-up period (16 months) without relapses.

\section{Case 2}

A 35-year-old married Caucasian woman reported to the department of gynecology with provoked LVP. She complained of vulvar pain for 36 months of evolution. She had a BMI of 25.7 and suffered from dysmenorrhea and endometriosis, with ovarian cystectomy at age 28 years. She had had 2 deliveries, the first with Cesarean section at age 29 years and the second with episiotomy and forceps at age 29 years, complicated by scar dehiscence that required 2 reparative interventions (the last at age 35 years). She used OCHC.

The vulvar pain, starting after the last reparative intervention for scar dehiscence, had itching and burning characteristics and was provoked by vaginal manipulation or contact, preventing intercourse and the application of tampons. Physical examination revealed vestibular palpation pain at 5 - and 8 -time zones without other abnormalities. The diagnosis orientation was provoked LVP. VAS at first visit was 100 .

Two sessions of procaine $0.5 \%$ injection were performed with an interval of 4 weeks on painful points (5- and 8-time zones). The patient presented pain of VAS $=20$ and scarce self-limiting bleeding related to the punctures. VAS after the intervention was 0 . The pain did not reappear during the follow-up period of 7 months. The patient was able to resume the use of tampons and intercourse normally.

\section{Case 3}

A 33-year-old married Caucasian woman reported to the gynecology department for provoked LVP for 18 months of evolution, starting after delivery. The pain appeared immediately after genital contact or manipulation with a VAS intensity of 100 , persisting for $2 \mathrm{~h}$ after contact. The pain prevented any genital contact, so she was not able to partake in sexual practices. She had a BMI of 26.5, had had 1 delivery with episiotomy at age 31 years, and used condoms as contraception. As a medication, she received promestriene (vaginal) and chlorhexidine (topical).

Physical examination revealed episiotomy scar and vestibular palpation pain at the 5 -time zone without other abnormalities.

Procaine $0.5 \%$ injection in a painful point, localized in the 5 -time zone, was performed. She reported pain of VAS $=70$ for a very brief duration (just at the puncture time) and scarce self-limiting bleeding related to the puncture. VAS after the intervention was 0.

The patient was able to resume intercourse and the use of tampons. There were no relapses during the follow-up period of 18 months.

Case 4

A 44-year-old married Caucasian woman with mixed LVP (provoked and spontaneous) for 4 months presented to a gynecology consultant. She had a BMI of 25.3 and suffered from dysmenorrhea. She had had 1 delivery by vacuum and episiotomy at age 35 years and used OCHC. She was on treatment with fluomizin (vaginal), antifungal (topical), and corticosteroids (topical).

The patient reported pain with itching and burning characteristics with baseline VAS $=80$ that increased to VAS $=100$ with any vulvar manipulation or contact. The pain impaired intercourse or the use of tampons. She had received various treatments before consultation: antifungal treatment for 7 days, vaginal dequalinium chloride ovules (fluomizin) for 6 days, topical corticosteroids for 2 weeks, and moisturizing creams (active treatment at consultation). None of these treatments had improved LVP.

Physical exploration revealed episiotomy scar and painful palpation at the 5-time zone without other abnormalities.

Procaine $0.5 \%$ injection $(0.5 \mathrm{~mL})$ was performed in the 5 -time zone in 2 sessions with an interval of 4 weeks. After the first session, the pain decreased from VAS $=100$ to 50 , and after the second 
Table 2. Description of localized vulvar pain

\begin{tabular}{lcllrll}
\hline & $\begin{array}{l}\text { Evolution, } \\
\text { months }\end{array}$ & $\begin{array}{l}\text { Patient } \\
\text { association }\end{array}$ & Stimulation & VAS & $\begin{array}{l}\text { Localization, } \\
\text { time zones }\end{array}$ & Characteristics \\
\hline Case 1 & 5 & - & Provoked & 70 & 5,7 & Itching \\
Case 2 & 36 & Delivery, forceps & Provoked & 100 & 5,8 & Burning, itching \\
Case 3 & 18 & Delivery & Provoked & 100 & 5 & Pain \\
Case 4 & 4 & - & Mixed & 100 & 5 & Burning, itching \\
Case 5 & 36 & Delivery, forceps & Provoked & 70 & 5 & Burning, itching \\
\hline
\end{tabular}

Table 3. Description of treatment with procaine $0.5 \%$ and clinical evolution

\begin{tabular}{|c|c|c|c|c|c|c|}
\hline & \multirow{2}{*}{$\begin{array}{l}\text { Injection points, } \\
\text { time zones }\end{array}$} & \multirow{2}{*}{$\begin{array}{l}\text { Number of } \\
\text { sessions }\end{array}$} & \multicolumn{2}{|l|}{ VAS } & \multirow{2}{*}{$\begin{array}{l}\text { Adverse effects of } \\
\text { the injections* }\end{array}$} & \multirow{2}{*}{$\begin{array}{l}\text { Follow-up, } \\
\text { months }\end{array}$} \\
\hline & & & initial & end & & \\
\hline Case 1 & 5,7 & 1 & 70 & 20 & $\begin{array}{l}\text { Pain VAS } 20 \\
\text { Scarce bleeding }\end{array}$ & 16 \\
\hline Case 2 & 5,8 & 2 & 100 & 0 & $\begin{array}{l}\text { Pain VAS } 20 \\
\text { Scarce bleeding }\end{array}$ & 7 \\
\hline Case 3 & 5 & 1 & 100 & 0 & $\begin{array}{l}\text { Pain VAS } 70 \\
\text { Scarce bleeding }\end{array}$ & 18 \\
\hline Case 4 & 5 & 2 & 100 & 30 & $\begin{array}{l}\text { Pain VAS } 20 \\
\text { Scarce bleeding }\end{array}$ & 10 \\
\hline Case 5 & 5, episiotomy scar & 1 & 70 & 30 & $\begin{array}{l}\text { Pain VAS } 20 \\
\text { Scarce bleeding }\end{array}$ & 18 \\
\hline
\end{tabular}

session from 50 to 30 . She presented pain of VAS $=20$ and scarce self-limiting bleeding related to the punctures.

The improvement was maintained during the follow-up of 10 months. The patient was able to resume coitus and the use of tampons.

\section{Case 5}

A 33-year-old married Caucasian woman with a prior medical history significant for Crohn's disease and hypothyroidism reported provoked LVP for 36 months. She had a BMI of 20.9 and suffered from dysmenorrhea and endometriosis. She had had 1 delivery at age 30 years with forceps and episiotomy (suffering from perineal second-grade tear). She used OCHC and vaginal ring. In addition, she had recurrent vulvovaginitis from age 25 years with the last episode at 32 years, having treatment with antifungal, either oral or topical in each episode. She was on treatment with azathioprine (oral), mesalazine (rectal), and levothyroxine (oral). She complained from vulvar pain immediately after contact with burning and itching characteristics and VAS $=70$. The pain impaired intercourse and the use of tampons.

Physical exploration revealed pain in the 5-time zone and episiotomy scar without other abnormalities.

Procaine $0.5 \%(0.7 \mathrm{~mL})$ injection was performed into the 5 -time zone and episiotomy scar (painful points) in 2 sessions with an interval of 4 weeks. She presented pain of VAS $=20$ and scarce self-limiting bleeding related to the punctures. After the first intervention, pain improved from VAS $=70$ to 40 , and after the second, VAS decreased to 30 . The patient was able to resume intercourse and the use of tampons. There were no relapses during the followup period of 18 months.
Table 1 summarizes the demographic and clinical characteristics of the women; Table 2 describes the main characteristics of LVP; and Table 3 summarizes treatment and clinical evolution.

\section{Discussion}

\section{Findings and Interpretation}

In our case series, subcutaneous procaine injection was found to be a fast and safe treatment for LVP. Since it is a minimally invasive technique, the treatment can be performed on an outpatient basis. The fact that only 1 or 2 sessions resolved a chronic problem is another outstanding result of this technique. The fact that patients could resume sexual intercourse after the intervention is another remarkable point.

To our knowledge, this is the first case series to describe subcutaneous procaine injection to treat LVP.

\section{Similarities and Differences in the Literature Review}

Topical application of LA is one of the most commonly prescribed treatments for vulvodynia [17]. In contrast, repeated applications of lidocaine are considered an elective treatment for this condition with variable outcomes. A common side effect is stinging, which causes many pa- 
Table 4. Anti-inflammatory effects of LA

\begin{tabular}{|c|c|c|}
\hline Actions over leukocyte & $\begin{array}{l}\text { Actions over synthesis and release } \\
\text { of inflammatory agents }\end{array}$ & Actions on vascular edema \\
\hline $\begin{array}{l}\text { Inhibition of leukocyte adhesion to vascular } \\
\text { endothelium [26] }\end{array}$ & Inhibition of the release of lysosomal enzymes [30] & $\begin{array}{l}\text { Inhibition of the increase in } \\
\text { vascular permeability [14] }\end{array}$ \\
\hline Inhibition of leukocyte motility [27] & $\begin{array}{l}\text { Inhibition of the synthesis and release of mediators } \\
\text { of inflammation (PG, TXA, and LT); phospholipase } \\
\text { A2 (PLA2) [31-33] }\end{array}$ & \\
\hline $\begin{array}{l}\text { Attenuation of the release of chemotactic } \\
\text { agents [28] }\end{array}$ & $\begin{array}{l}\text { Decreased release of proinflammatory cytokines } \\
\text { (IL-8, IL-1b, and TNF- } \alpha \text { ) and anti-inflammatory } \\
\text { stimulant (IL-1a) [34] }\end{array}$ & \\
\hline $\begin{array}{l}\text { Interference in the process of activation } \\
\text { and priming of neutrophils }[24,28]\end{array}$ & $\begin{array}{l}\text { Decreased synthesis of superoxide anions and free } \\
\text { radicals [35] }\end{array}$ & \\
\hline \multicolumn{3}{|l|}{ Reduction of phagocytic activity [29] } \\
\hline $\begin{array}{l}\text { Inhibition of the metabolic activity of } \\
\text { leukocytes [28] }\end{array}$ & & \\
\hline
\end{tabular}

tients to discontinue treatment [9]. In contrast, subcutaneous injections of procaine $0.5 \%$ in our series of cases were shown to improve symptoms, requiring only 1 or 2 sessions. The difference in the route of administration of LA (subcutaneous versus topical) could influence the different outcomes and treatment tolerance. The generation of a directed stimulus (caused by the needle) and the selective extinction of other stimuli (by means of LA) could have an impact on the organization of the nervous system and tissue perfusion, interrupting positive feedback actions (vicious circle) of pain $[12,13,15]$.

The infiltration with ropivacaine of the impar ganglion has been previously described for treatment of rebel vulvodynia with good favorable results in a case series with 8 patients [18]. The main difference in our case series is the requirement of computed tomography and contrast injection. In addition, in 2 patients botulinic toxin was also administrated. As in our case series, the improvement was maintained over time without requiring other treatments during the follow-up period.

Weinschenk et al. [10] reported a case of long-lasting vulvodynia successfully treated with repeated injections of procaine $1 \%$ in HEAD's zone and trigger points of different locations and interference fields (abdomen, hypogastrium, maxillary, and scar jaw). The patient received 14 sessions and the improvement was maintained in the follow-up period. The main differences from our case series are the number of injections (much lower in our case series) and the points of injections (distant from the vulvar area in that case vs. exclusively in the vulvovaginal area in our case series).

In our case series, the adverse effects were limited to a brief pain at the puncture site without residual discomfort afterwards. This finding coincides with the results of oth- er studies in the medical literature, considering the injection of LA at low concentrations as a safe intervention in the management of pain control $[10,12,18-20]$.

\section{Mechanisms of Action of $L A$}

The therapeutic effect of LA has been mainly related to their nerve-blocking properties, secondary to their interaction with the $\mathrm{Na}^{2+}$ channels. During the last few decades, a wide range of attributes, beyond their anesthetic effect, have been related to LA, probably due to their action over the $\mathrm{K}^{+}$and $\mathrm{Ca}^{2+}$ channels [21], inhibitory actions on the receptors coupled to the protein G [14], and inhibitory action on the $N$-methyl-D-aspartate (NMDA) receptors $[22,23]$.

The modulating effects of LA on the immune system have been widely described $[14,24]$, and different mechanisms of action have been proposed [14, 25-36]: leucocyte inhibition, decrease in synthesis and release of inflammatory mediators, and decrease in vascular hyperpermeability and edema formation (Table 4).

The modulating effects of LA on the neural system have also been previously described in the medical literature. LA may interrupt the vicious circle of nociceptor acting over different pathogenic mechanisms involved in pain perception, such as sympathetic excitation, vascular alteration, neurogenic inflammation, and muscular contraction $[12,14]$.

Our case series raises the question about the role of LA in the treatment of chronic pain and their long-acting analgesic action. In the medical literature, we find reports about the therapeutic effects of LA beyond their anesthetic local effect, showing favorable evolution of chronic pain treated with injections of LA [12, 13, 37-41]. Puente de la Vega Costa et al. [15] summarize the following 
mechanisms of action of the LA to explain their lasting effects on pain: reduction of long-term potentiation in the sympathetic ganglia $[42,43]$, decrease of sympathetic sprouting related to sympathetic-afferent coupling [4446], decrease of the inflammation related to vasomotor phenomena [47], decrease of the release of proinflammatory neuropeptides from sympathetic fibers [14, 47], decrease of the sympathetically mediated activity of wide dynamic range neurons [48], interruption of interaction between the sympathetic nervous system and immune system $[47,49]$, temporary interruption of the positive feedback neuronal circuits ("reset"), with the involvement of the sympathetic nervous system at the spinal and supraspinal levels and the subsequent reorganization of the systems involved $[12,13]$.

The etiopathogenic mechanisms related to LVP described previously are focused on a neurogenic and/or inflammatory origin. Regardless of whether LVP starts with nerve injury or a chronic inflammatory process, the alteration (irritation) of the vestibular nerve endings and the modification of nerve transmission occur originating anomalous impulses [50]. This causes peripheral sensitization that, when maintained over time or by very intense stimuli, gives rise to central sensitization and perpetuation of pain [12]. Treatment with local modality of NT could eliminate the anomalous stimuli of the central nervous system and, consequently, resolve the pain.

\section{Conclusions}

None of the treatments proposed up to now for LVP have shown to be effective in permanently improving the symptoms. The results of our case series of 5 patients with
LVP suggest that local injection with procaine may be an option to consider, whether it is applied primarily or after insufficient standard procedures. Well-designed studies should be done to assess the efficacy of this treatment in LVP.

\section{Acknowledgement}

We thank Paloma Lobo Abascal for her comments on the article. We also thank all the women who participated in the study.

\section{Statement of Ethics}

An informed consent was obtained for this minimally invasive treatment modality. All patients gave their informed consent for the publication of this study.

\section{Conflict of Interest Statement}

The authors declare that they have no competing interests.

\section{Funding Sources}

The authors received no external funding to conduct this study.

\section{Author Contributions}

M.R.N. conceived the idea, carried out the fieldwork, and contributed to drafting the manuscript and reviewing the literature. M.M.-S. wrote the final manuscript and contributed to reviewing the literature. M.C.S. contributed to drafting the manuscript. D.V.C. contributed to reviewing the literature and revised the paper. All authors read and approved the final manuscript.

\section{References}

1 Bornstein J, Goldstein AT, Stockdale CK, Bergeron S, Pukall C, Zolnoun D, et al.; consensus vulvar pain terminology committee of the International Society for the Study of Vulvovaginal Disease (ISSVD), the International Society for the Study of Women's Sexual Health (ISSWSH), and the International Pelvic Pain Society (IPPS). 2015 ISSVD, ISSWSH and IPPS consensus terminology and classification of persistent vulvar pain and vulvodynia. Obstet Gynecol. 2016 Apr; 127(4):745-51.

2 Bonham A. Vulvar vestibulodynia: strategies to meet the challenge. Obstet Gynecol Surv. 2015 Apr;70(4):274-8.

3 Reed BD, Harlow SD, Sen A, Legocki LJ, Edwards RM, Arato N, et al. Prevalence and demographic characteristics of vulvodynia in a population-based sample. Am J Obstet Gynecol. 2012 Feb;206(2):170.e1-9.

4 Harlow BL, Stewart EG. A population-based assessment of chronic unexplained vulvar pain: have we underestimated the prevalence of vulvodynia? J Am Med Womens Assoc (1972). 2003;58(2):82-8

5 Arnold LD, Bachmann GA, Rosen R, Rhoads GG. Assessment of vulvodynia symptoms in a sample of US women: a prevalence survey with a nested case control study. Am J Obstet Gynecol. 2007 Feb;196(2):128.e1-6.

6 Akopians AL, Rapkin AJ. Vulvodynia: The Role of Inflammation in the Etiology of Localized Provoked Pain of the Vulvar Vestibule (Vestibulodynia). Semin Reprod Med. 2015 Jul;33(4):239-45.

7 Granot M, Lavee Y. Psychological factors associated with perception of experimental pain in vulvar vestibulitis syndrome. J Sex Marital Ther. 2005 Jul-Sep;31(4):285-302.

8 Alappattu MJ, Bishop MD. Psychological factors in chronic pelvic pain in women: relevance and application of the fear-avoidance model of pain. Phys Ther. 2011 Oct;91(10): 1542-50.
9 De Andres J, Sanchis-Lopez N, Asensio-Samper JM, Fabregat-Cid G, Villanueva-Perez VL, Monsalve Dolz V, et al. Vulvodynia-An Evidence-Based Literature Review and Proposed Treatment Algorithm. Pain Pract. 2016 Feb;16(2):204-36.

10 Weinschenk S, Brocker K, Hotz L, Strowitzki T, Joos S; HUNTER (Heidelberg University Neural Therapy Education and Research) Group. Successful therapy of vulvodynia with local anesthetics: a case report. Forsch Komplementmed. 2013;20(2):138-43.

11 Goldstein AT, Pukall CF, Brown C, Bergeron S, Stein A, Kellogg-Spadt S. Vulvodynia: assessment and Treatment. J Sex Med. 2016 Apr;13(4):572-90.

12 Egli S, Pfister M, Ludin SM, Puente de la Vega K, Busato A, Fischer L. Long-term results of therapeutic local anesthesia (neural therapy) in 280 referred refractory chronic pain patients. BMC Complement Altern Med. 2015 Jun;15(1):200. 
13 Nazlıkul H, Ural FG, Öztürk GT, Öztürk AD. Evaluation of neural therapy effect in patients with piriformis syndrome. J Back Musculoskeletal Rehabil. 2018;31(6):1105-10.

14 Cassuto J, Sinclair R, Bonderovic M. Anti-inflammatory properties of local anesthetics and their present and potential clinical implications. Acta Anaesthesiol Scand. 2006 Mar; 50(3):265-82.

15 Puente de la Vega Costa K, Gómez Perez MA, Roqueta C, Fischer L. Effects on hemodynamic variables and echocardiographic parameters after a stellate ganglion block in 15 healthy volunteers. Auton Neurosci. 2016 May; 197: 46-55.

16 Weinschenk S, Göllner R, Hollmann MW, Hotz L, Picardi S, Hubbert K, et al.; Heidelberg University Neural Therapy Education and Research Group (The HUNTER group). Inter-Rater Reliability of Neck Reflex Points in Women with Chronic Neck Pain. Forsch Komplementmed. 2016;23(4):223-9.

17 Peng PW, Tumber PS. Ultrasound-guided interventional procedures for patients with chronic pelvic pain - a description of techniques and review of literature. Pain Physician. 2008 Mar-Apr;11(2):215-24.

18 Cardaillac C, Ploteau S, Labat JJ, Levesque A, Riant T. Intérêt de l'infiltration du ganglion Impar dans les vulvodynies rebelles: à propos d'une série de 8 cas [Interest of infiltration of Impar node in rebel vulvodynia: About a series of 8 cases]. Prog Urol. 2016 Dec;26(17): 1213-21.

19 Weinschenk S, Hollmann MW, Göllner R, Picardi S, Strowitzki T, Diehl L, et al. Injections of local anesthetics into the pharyngeal region reduce trapezius muscle tenderness. Forsch Komplementmed. 2016;23(2):111-6.

20 Yalçln Bahat P, Yüksel Özgör B, Turan G, Topbaş Selçuki NF, Nazllkul H. The effect of neural therapy on long-term postoperative discomforts after bilateral tubal ligation. Complement Med Res. 2020 Apr;21:1-5.

21 Scholz A. Mechanisms of (local) anaesthetics on voltage-gated sodium and other ion channels. Br J Anaesth. 2002 Jul;89(1):52-61.

22 Hahnenkamp K, Durieux ME, Hahnenkamp A, Schauerte SK, Hoenemann CW, Vegh V, et al. Local anaesthetics inhibit signalling of human NMDA receptors recombinantly expressed in Xenopus laevis oocytes: role of protein kinase C. Br J Anaesth. 2006 Jan;96(1): 77-87.

23 Sugimoto M, Uchida I, Mashimo T. Local anaesthetics have different mechanisms and sites of action at the recombinant $\mathrm{N}$-methylD-aspartate (NMDA) receptors. Br J Pharmacol. 2003 Mar;138(5):876-82.

24 Hollmann MW, Durieux ME, Fisher DM. Local anesthetics and the inflammatory response: a new therapeutic indication? Anesthesiology. 2000 Sep;93(3):858-75.

25 Hollmann MW, Gross A, Jelacin N, Durieux ME. Local anesthetic effects on priming and activation of human neutrophils. Anesthesiology. 2001 Jul;95(1):113-22.
26 Schmidt W, Schmidt H, Bauer H, Gebhard MM, Martin E. Influence of lidocaine on endotoxin-induced leukocyte-endothelial cell adhesion and macromolecular leakage in vivo. Anesthesiology. 1997 Sep;87(3):617-24.

27 Schmid RA, Yamashita M, Ando K, Tanaka Y, Cooper JD, Patterson GA. Lidocaine reduces reperfusion injury and neutrophil migration in canine lung allografts. Ann Thorac Surg. 1996 Mar;61(3):949-55.

28 Guthrie LA, McPhail LC, Henson PM, Johnston RB Jr. Priming of neutrophils for enhanced release of oxygen metabolites by bacterial lipopolysaccharide. Evidence for increased activity of the superoxide-producing enzyme. J Exp Med. 1984 Dec;160(6):165671.

29 Kiefer RT, Ploppa A, Krueger WA, Plank M, Nohé B, Haeberle HA, et al. Local anesthetics impair human granulocyte phagocytosis activity, oxidative burst, and CD11b expression in response to Staphylococcus aureus. Anesthesiology. 2003 Apr;98(4):842-8.

30 Lyubchenko TA, Wurth GA, Zweifach A. The actin cytoskeleton and cytotoxic $\mathrm{T}$ lymphocytes: evidence for multiple roles that could affect granule exocytosis-dependent target cell killing. J Physiol. 2003 Mar;547(Pt 3): 835-47.

31 Beloeil H, Gentili M, Benhamou D, Mazoit JX. The effect of a peripheral block on inflammation-induced prostaglandin E2 and cyclooxygenase expression in rats. Anesth Analg. 2009 Sep;109(3):943-50.

32 Kunze H, Nahas N, Traynor JR, Wurl M. Effects of local anaesthetics on phospholipases. Biochim Biophys Acta. 1976 Jul;441(1):93102.

33 Gonzales R, Goldyne ME, Taiwo YO, Levine JD. Production of hyperalgesic prostaglandins by sympathetic postganglionic neurons. J Neurochem. 1989 Nov;53(5):1595-8.

34 Lahav M, Levite M, Bassani L, Lang A, Fidder $\mathrm{H}$, Tal R, et al. Lidocaine inhibits secretion of IL- 8 and IL- $1 \beta$ and stimulates secretion of IL-1 receptor antagonist by epithelial cells. Clin Exp Immunol. 2002 Feb;127(2):226-33.

35 Chan DS, Wang HH. Local anesthetics can interact electrostatically with membrane proteins. Biochim Biophys Acta. 1984 Feb; 770(1):55-64.

36 Suzuki T, Ohishi K, Kida J, Uchida M. Influence of $\mathrm{pH}$ on the inhibitory effects of local anesthetics on histamine release induced from rat mast cells by concanavalin A and compound 48/80. Eur J Pharmacol. 1984 Mar; 98(3-4):347-55.

37 Lóriz Peralta O, Raya Rejón A, Pérez Morales D, Girona Amores A, Vinyes Casajoana D, Puente de la Vega Costa K. [Intervention study on subacute and chronic pain in primary care: an approach to the effectiveness of neural therapy] [Spanish]. Aten Primaria. 2011 Nov;43(11):604-10.
38 Kronenberg RM, Ludin SM, Fischer L. Severe Case of Chronic Pelvic Pain Syndrome: recovery after injection of procaine into the vesicoprostatic plexus-case report and discussion of pathophysiology and mechanisms of action. Case Rep Urol. 2018 Jun;2018:9137215.

39 Ural FG, Öztürk GT, Nazlıkul H. Evaluation of neural therapy effects in patients with lateral epicondylitis: a randomized controlled trial. Ankara Med J. 2017;17(4):260-6.

40 Villamizar Olarte DM, Rojas de Rangel D. Eficacia de la terapia neural en pacientes con dolor cervical o lumbar, del servicio de medicina física y rehabilitación de un centro hospitalario, 2016. [Effectiveness of neural therapy in patients with neck pain or low back pain, of rehabilitation unit, 2016]. Rev Colomb Médicina Física y Rehabil. 2017;27(1):25-37.

41 Trevín Fernández G, Palma Febres A, Santoya Varela V, Expósito Reyes O. Efectividad de la terapia neural en el dolor lumbosacro agudo de tipo mecánico. [Effectiveness of neural therapy in the acute lumbosacral of mechanical type]. Multimed. 2012;16(suppl 1):72332 .

42 Kansha M, Nagata T, Irita K, Takahashi S. Dibucaine and tetracaine inhibit the activation of mitogen-activated protein kinase mediated by L-type calcium channels in PC12 cells. Anesthesiology. 1999 Dec;91(6):1798-806.

43 Tan Z, Dohi S, Ohguchi K, Nakashima S, Nozawa Y. Local anesthetics inhibit muscarinic receptor-mediated activation of extracellular signal-regulated kinases in rat pheochromocytoma PC12 cells. Anesthesiology. 1999 Oct; 91(4):1014-24.

44 Chung K, Chung JM. Sympathetic sprouting in the dorsal root ganglion after spinal nerve ligation: evidence of regenerative collateral sprouting. Brain Res. 2001 Mar;895(1-2): 204-12.

45 Zhang Y, Popović ZB, Bibevski S, Fakhry I, Sica DA, Van Wagoner DR, et al. Chronic vagus nerve stimulation improves autonomic control and attenuates systemic inflammation and heart failure progression in a canine high-rate pacing model. Circ Heart Fail. 2009 Nov;2(6):692-9.

46 Takatori M, Kuroda Y, Hirose M. Local anesthetics suppress nerve growth factor-mediated neurite outgrowth by inhibition of tyrosine kinase activity of TrkA. Anesth Analg. 2006 Feb;102(2):462-7.

47 Jänig W. Sympathetic nervous system and inflammation: a conceptual view. Auton Neurosci. 2014 May;182:4-14.

48 Roberts WJ, Foglesong ME. Spinal recordings suggest that wide-dynamic-range neurons mediate sympathetically maintained pain. Pain. 1988 Sep;34(3):289-304.

49 Straub RH, Wiest R, Strauch UG, Härle P, Schölmerich J. The role of the sympathetic nervous system in intestinal inflammation. Gut. 2006 Nov;55(11):1640-9.

50 Tympanidis P, Terenghi G, Dowd P. Increased innervation of the vulval vestibule in patients with vulvodynia. Br J Dermatol. 2003 May;148(5):1021-7. 